\title{
Effect of Photovoltaic (PV) Module Degradation Rate on The Greenhouse Gas Emissions: A Life-Cycle Assessment
}

\author{
Atiqah Hamizah Mohd Nordin, Shahril Irwan Sulaiman, Sulaiman Shaari, and Rijalul Fahmi Mustapa.
}

\begin{abstract}
In this paper, a life-cycle assessment (LCA) is carried out to evaluate the greenhouse gas emissions of the photovoltaic (PV) system, focusing on the effect of the PV module degradation rate throughout the system's lifetime. The LCA is done on monocrystalline silicon PV module technology using actual data from manufacturers' datasheets. In this study, three different manufacturers under three scenarios are done, which involves the inclusion and exclusion of the degradation factor: i) Scenario A PV module degradation is considered with a PR of 0.75 , ii) Scenario B - PV module degradation is considered and the PR is calculated based on each PV module's temperature coefficient and other de-rating factors, iii) Scenario C - PV module degradation is ignored. Using the Intergovernmental Panel of Climate Change (IPCC 2013) impact assessment method, the results show that the greenhouse gas (GHG) emissions rate ranges from 66.05 to 79.25 $\mathrm{g} \mathrm{CO}_{2}$-eq/kWh depending on the scenarios presented. The results also suggest that a lower degradation rate reduces the environmental burden of the PV system.
\end{abstract}

Index Terms-GHG emissions, global warming, degradation rate, life cycle assessment, LCA, photovoltaic, mono-Si.

\section{INTRODUCTION}

$\mathrm{T}$ HERE is no doubt that photovoltaic (PV) is a popular renewable energy (RE) technology that generates electricity from cleaner resources compared to fossil-fuel based resources, e.g., coal or oil. However, an increasing number of life-cycle assessment (LCA) studies reveal that PV still produces greenhouse gas (GHG) emissions when considering the life-cycle stages of the system, i.e., raw material extraction, manufacturing, transportation, installation, operation,

This manuscript is submitted on 1st December 2020 and accepted on 17th February 2021. This work was supported in part by the Fundamental Research Grant Scheme (FRGS), Ministry of Education (Ref: 600-IRMI/FRGS 5/3 (221/2019) and Universiti Teknologi MARA (UiTM) Malaysia.

Atiqah Hamizah Mohd Nordin is with Universiti Teknologi MARA, Johor Branch, Pasir Gudang Campus, 81750, Malaysia. (e-mail: atiqah.hamizah@gmail.com, atiqah26@uitm.edu.my).

Shahril Irwan Sulaiman is with Universiti Teknologi MARA, Shah Alam 40450, Malaysia. (e-mail: shahril@uitm.edu.my).

Sulaiman Shaari is with Universiti Teknologi MARA, Shah Alam 40450, Malaysia. (e-mail: solarman@uitm.edu.my).

Rijalul Fahmi Mustapa is with Universiti Teknologi MARA, Johor Branch, Pasir Gudang Campus, 81750, Malaysia. (e-mail: rijalulfahmi@uitm.edu.my).

1985-5389/C 2021 The Authors. Published by UiTM Press. This is an open access article under the CC BY-NC-ND license (http://creativecommons.org/ licenses/by-nc-nd/4.0/). maintenance, and end-of-life (EoL) activities. However, an increasing number of life-cycle assessment (LCA) studies reveal that PV still produces greenhouse gas (GHG) emissions when considering the life-cycle stages of the system, i.e., raw material extraction, manufacturing, transportation, installation, operation, maintenance, and end-of-life (EoL) activities.

Kato et al. [1] conducted an LCA of a rooftop grid-connected (GC) PV system in Japan with irradiation of $1,427 \mathrm{kWh} / \mathrm{m}^{2} / \mathrm{y}$, using monocrystalline silicon (mono-Si) PV module made of off-grade silicon. Assuming a performance ratio (PR) of 0.81, system lifetime of 20 years, and a cradle-to-gate system boundary, the GHG emissions ranged from 21 to $91 \mathrm{~g} \mathrm{CO}_{2}$ eq/kWh, depending on different processing considerations. Alsema [2] compared the GHG emissions of rooftop PV systems using two different PV module technologies: multicrystalline silicon (multi-Si) and amorphous silicon (a-Si). According to the authors, the study boundary only covered the production of PV modules and BOS components, due to negligible energy consumption during operational phase and lack of PV EoL data. It was found that the PV system with a-Si module had lower emissions of $50 \mathrm{~g} \mathrm{CO}_{2}$-eq/ $\mathrm{kWh}$ than the former with $60 \mathrm{~g} \mathrm{CO}_{2}$-eq/kWh, under irradiation of 1,700 $\mathrm{kWh} / \mathrm{m}^{2} / \mathrm{y}$, and PR of 0.75 .

Meanwhile, an LCA of a large-scale PV system in Marsciano, Italy, with an installed capacity of $1.778 \mathrm{MWp}$, was investigated by Desideri et al. [3]. The installation was different from the rooftop or small-scale PV system, including additional infrastructure such as fence, and electrical substation. The GHG emissions of $88.74 \mathrm{~g} \mathrm{CO}_{2}$-eq/kWh was obtained using multi-Si PV module with module efficiency of $14.4 \%$ and system lifetime of 25 years, taking into account a recycling scenario at its EoL phase. Beylot et al. [4] compared four different scenarios of PV system installation type: i) fix mounting structure with primary aluminium support, ii) fix mounting structure with wood support, iii) mobile structure with singleaxis tracker, and iv) mobile structure with dual-axis tracker. The finding showed that the first scenario had the highest GHG emissions due to the high carbon footprint of the primary aluminium, even considering the environmental credits from the recovery of aluminium through recycling at EoL. The results ranged from 37.5 to $53.5 \mathrm{~g} \mathrm{CO}_{2}$-eq/kWh, under 
irradiation, module type, system capacity, system lifetime, and PR of $1,700 \mathrm{kWh} / \mathrm{m}^{2} / \mathrm{y}$, multi-Si, $5 \mathrm{MWp}, 30$ years, and 0.855 , respectively.

The reported GHG emissions showed a wide range of results, and several factors had been highlighted as the main influence on the results, such as solar irradiation, PR, system lifetime, type of installation, and system boundary considered [5]-[10]. The system's lifetime of 25 to 30 years was mostly considered in previous studies. During this period, the performance of the PV module will eventually degrade over time. Nevertheless, many of previous studies had not mentioned whether the PV module degradation was taken into account or not in their studies. There were also studies that clearly stated the value of degradation rate considered [3], [11]-[14]. In the International Energy Agency Photovoltaic Power Systems (IEA-PVPS) guideline, the recommended degradation rate is $0.7 \% / y$ ear or $10.5 \%$ in the entire lifetime [15]. Nevertheless, nowadays, a lower degradation rate can be found in new PV module datasheets. In this paper, we demonstrate the impact of the PV module degradation over the system's lifetime on GHG emissions in order to highlight the importance of the factor from the environmental point of view.

\section{Methodology}

A case study of $3.45 \mathrm{kWp}$ slanted-roof GCPV system installed in Kuala Lumpur, Malaysia with annual solar irradiation of $1,695.72 \mathrm{kWh} / \mathrm{m}^{2} / \mathrm{y}$ was considered. Mono-Si PV modules from three different manufacturers with similar nominal power rating were selected for comparison, with the technical specification listed in Table I. The system was assumed to consist of ten units of $345 \mathrm{~W}$ modules. The system was assumed to be in operation for 30 years, based on the IEAPVPS guideline [15]. Within this period, the annual electricity generation will reduce as the operating year increases. Equation 1 is used to estimate the annual electricity generation of the PV system. For a cumulative electricity generation throughout the lifetime, $E_{\text {sys_lifetime, }}$ the parameter of lifetime module degradation factor, $f_{\text {mod_degrade_lifetime }}$ is multiplied to the Equation 1.

TABLE I

SPECIFICATIONS OF MONOCRYSTALLINE SILICON PV MODULES

\begin{tabular}{lcccc}
\hline \hline Parameter & Unit & SunPower & Longi & Jinko Solar \\
\hline Model & -- & SPR-X21-345- & LR4-60HPB- & JKM345M-72 \\
& & COM & $345 \mathrm{M}$ & \\
$P_{\text {mod_stc }}$ & $\mathrm{W}$ & 345 & 345 & 345 \\
$\eta_{\text {mod }}$ & $\%$ & 21.2 & 18.9 & 17.78 \\
$\gamma_{\text {Pmp }}$ & $\%{ }^{\circ} \mathrm{C}$ & -0.298 & -0.35 & -0.40 \\
$f_{o}$ & $\%$ & 98 & 98.5 & 97 \\
$x$ & $\%$ & 0.25 & 0.55 & 0.7 \\
\hline \hline
\end{tabular}

The PR of a PV system is influenced by several design factors, namely temperature, dirt, module mismatch, cable losses, and inverter efficiency, as expressed in Equation 2. For a rooftop installation, depending on situation, a PR of 0.75 is common, as recommended in the IEA-PVPS guideline. However, a more accurate value can be estimated according to the module's temperature coefficient declared by the manufacturer and expert judgement for other de-rating factors. In this study, assumptions of $f_{\text {dirt }}, f_{m m}, f_{\text {cable }}$, and $\eta_{\text {inv }}$ were 0.95 , $0.95,0.98$, and 0.96 , respectively were made [16]. The temperature de-rating factor, $f_{\text {temp_ave }}$ was estimated using Equation 3 and 4, where the cell temperature, $T_{\text {cell_ave }}$ was $58.56^{\circ} \mathrm{C}$, assuming the ambient temperature $T_{\text {amb_ave_max }}$, nominal operating cell temperature (NOCT), and irradiance, $G_{\text {amb_ave_max }}$ were $32^{\circ} \mathrm{C}, 45^{\circ} \mathrm{C}$, and $850 \mathrm{~W} / \mathrm{m}^{2}$, respectively [16].

$$
\begin{aligned}
& E_{\text {sys_annual }}=P_{\text {array_stc }} \times H_{\text {annual }} \times f_{\text {design }} \\
& f_{\text {design }}=f_{\text {temp_ave }} \times f_{\text {dirt }} \times f_{m m} \times f_{\text {cable }} \times \eta_{\text {inv }} \\
& f_{\text {temp_ave }}=1+\left[\left(\frac{\gamma_{P m p}}{100}\right) \times\left(T_{\text {cell_ave }}-T_{\text {stc }}\right)\right] \\
& T_{\text {cell_ave }}=T_{\text {amb_ave_max }}+\left[\left(\frac{N O c T-20}{800}\right) \times G_{\text {amb_ave_max }}\right]
\end{aligned}
$$

PV module degradation is a gradual deterioration that affects its output power generation over time. In general, the degradation is caused by several factors: temperature, humidity, irradiation, corrosion, discoloration, delamination, and breakage or cracking cells [17]. In the first year, the PV module usually degrades at a certain percentage of the warranted output power $\left(f_{o}\right)$. In the following years ahead, the output power usually degrades linearly with a degradation rate $(x)$ [18], as commonly described in PV module datasheets. Based on the manufacturers' warranty, the degradation is linear from the first year until 25 years, as illustrated in Figure 1. In this study, we assume that it is extended to 30 years. Thus, the module degradation factor for the lifetime was derived and presented in Equation 5, which is further utilized in Equation 6 to determine the total generated electricity throughout the lifetime, $E_{\text {sys_lifetime }}$. In Figure 1, it is observed that the SunPower module has the slowest annual degradation rate, while Jinko Solar has the fastest.

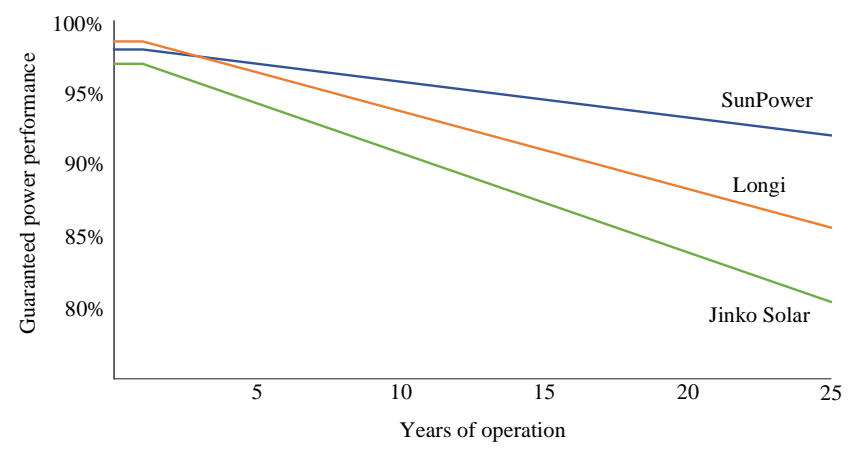

Fig. 1. Power performance over years of operation.

$f_{\text {mod_degrade_lifetime }}=f_{o} t-x \frac{t(t-1)}{2}$ 
Where,

$f_{o}$ is initial degradation factor (absolute value)

$x$ is annual degradation rate (absolute value)

$t$ is operating year

$E_{\text {sys_lifetime }}=P_{\text {array_stc }_{-}} \times H_{\text {annual }} \times f_{\text {design }} \times$

$f_{\text {mod_degrade_lifetime }}$

In this study, three scenarios are considered: i) Scenario A PV module degradation is considered with a PR of 0.75 , ii) Scenario B - PV module degradation is considered and the PR is calculated based on each PV module's temperature coefficient, and the above-mentioned de-rating factors, iii) Scenario C - PV module degradation is ignored. The flowchart of the study is illustrated in Figure 2. After the $E_{\text {sys_lifetime }}$ is determined, the input flows in the unit process are related according to the functional unit of $1 \mathrm{kWh}$ electricity generation. In the LCA framework outlined in the ISO 14040 and 14044, there are four stages involved in conducting an LCA study: i) goal and scope definition, ii) life cycle inventory (LCI), iii) life cycle impact assessment (LCIA), and iv) interpretation. The goal of this study is to investigate the influence of mono-Si PV module degradation factor on the GHG emissions. The system boundary encompasses the cradle-to-gate approach which covers most of the system's lifecycle stages including the raw material extraction, PV module, and balance of system (BOS) component production, installation, and operational and maintenance. Nevertheless, the EoL stage which may involve activities such as system decommissioning, reuse, and recycling of some parts of the system is excluded due to a lack of data considering the amount of EoL PV waste in the country as in the case study is relatively low.

The LCI is a set of data consisting information on material, energy consumption, and direct emissions of a process or system, interrelated with the functional unit. In this study, the LCI is adopted from the Ecoinvent 3.5 database, where the default $3 \mathrm{kWp}$ PV system dataset in the database is up-scaled to $3.45 \mathrm{kWp}$. The LCI covers complete mono-Si PV module production chains including metallurgical silicon production, mono-Si ingot production using the Czochralski process, wafer production, PV cell production, and PV module assembly. The production and installation of BOS components such as mounting structure, inverter, and cabling are also included. Moreover, the operation and maintenance such as PV module cleaning is also taken into account [19]. Subsequently, the GHG emissions results are generated using the IPCC 2013 LCIA method, embedded in the Simapro 9 software. In this stage, the emission substances are classified and characterized based on the characterization factor of the global warming potential (GWP 100) provided by the IPCC. The GHG emissions rate is reported in ' $\mathrm{g} \mathrm{CO}$-eq $/ \mathrm{kWh}$ ', where all types of involving greenhouse gases $\left(\mathrm{CH}_{4}, \mathrm{~N}_{2} \mathrm{O}\right.$, etc.) are converted into their equivalent impact magnitude of $\mathrm{CO}_{2}$ based on the characterization factors, which can be written as in Equation 7. Finally, the GHG emissions obtained for each scenario are compared.
$G H G$ emissions $=\sum_{s} G W P_{s} \times m_{s}$

Where,

$s$ is the substance

$G W P_{s}$ is the characterization factor of substance $s$

$m_{s}$ is the emitted amount of substance $s$ in $\mathrm{kg}$

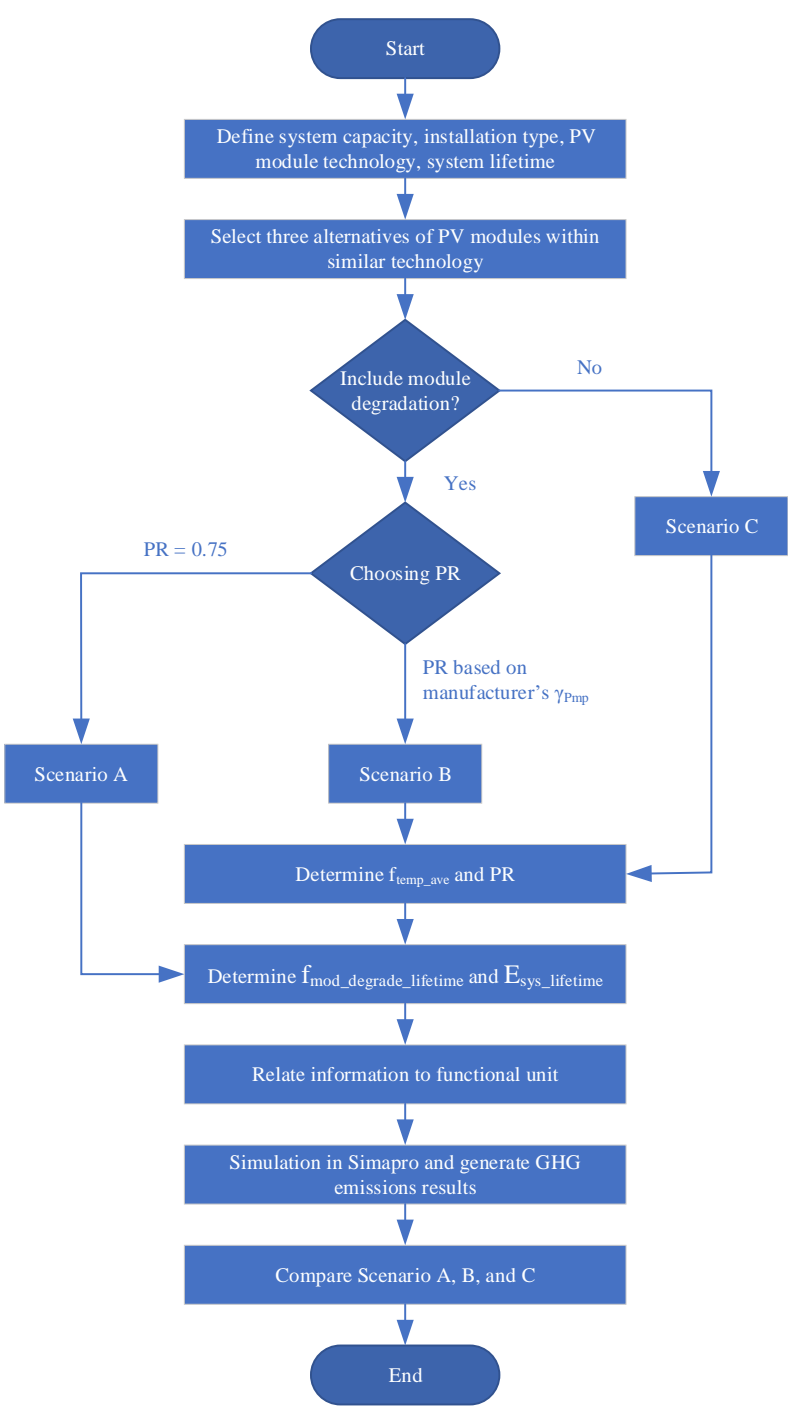

Fig. 2. Flowchart of the study.

\section{RESULT AND DISCUSSION}

Table II outlines the GHG emissions rate obtained under different values of parameters $\left(f_{\text {mod_degrade_lifetime }}\right.$ and PR), for all scenarios. The correlation coefficients between variables in Scenario $\mathrm{A}, \mathrm{B}$, and $\mathrm{C}$ are all 1, which indicates a strong correlation. The GHG emissions rate obtained in this study ranges from 66.05 to $79.25 \mathrm{~g} \mathrm{CO}_{2}$-eq/kWh, which in percentage-wise is illustrated in Figure 3. It is observed that in all scenarios, the SunPower module has the lowest GHG emissions, which is mainly due to the lowest annual degradation rate compared to the other two modules; subsequently, the $E_{\text {sys_lifetime }}$ is greater. Meanwhile, when 
comparing between Scenario A and B, it can be seen that for the Jinko Solar module, considering PR calculated from the datasheet's power temperature coefficient has resulted in higher GHG emissions. On the contrary, the SunPower module produces lower emissions when the factor is taken into account. In other words, a lower power temperature coefficient will result in higher PR and subsequently lower GHG emissions. Note that the $f_{\text {mod_degrade_lifetime }}$ in Scenario $\mathrm{C}$ is equal to the system lifetime (30) due to no degradation considered over the lifetime.

In Scenario C, it is observed that when neglecting the PV module degradation, the emission is considerably lower compared to both Scenario A and B. Comparing to the most realistic case (Scenario B), $8.62 \%$ to $13.15 \%$ lower GHG emissions is obtained in Scenario C. Having similar conditions of solar irradiation, system lifetime, PV module types, and installation types for each scenario, the range of variation is considered high. This implies that considering the PV module degradation in estimating the environmental impact is crucial and should not have left out, which otherwise would cause an underestimation.

TABLE II

RESULTS FOR DIFFERENT SCENARIOS

\begin{tabular}{lcccc}
\hline \hline Parameter & $\begin{array}{c}\mathrm{f}_{\text {mod_degrad__lifetime }} \\
-\end{array}$ & $\begin{array}{c}\mathrm{PR} \\
-\end{array}$ & $\begin{array}{c}\mathrm{E}_{\text {sy__lifetime }}[\mathrm{kWh}] \\
\text { Scenario A }\end{array}$ & $\begin{array}{c}\text { GHG emissions } \\
{\left[\mathrm{g} \mathrm{CO}_{2} \text {-eq } / \mathrm{kWh}\right]}\end{array}$ \\
SunPower & 27.4125 & 0.750 & 120277.15 & 73.82 \\
Longi & 27.1575 & 0.750 & 119158.30 & 74.52 \\
Jinko Solar & 26.0550 & 0.750 & 114320.89 & 77.67 \\
Scenario B & & & & \\
SunPower & 27.4125 & 0.766 & 122843.07 & 72.28 \\
Longi & 27.1575 & 0.749 & 118999.42 & 74.61 \\
Jinko Solar & 26.0550 & 0.735 & 112034.47 & 79.25 \\
Scenario C & & & & \\
SunPower & 30 & 0.766 & 134438.38 & 66.05 \\
Longi & 30 & 0.749 & 131454.76 & 67.55 \\
Jinko Solar & 30 & 0.735 & 128997.66 & 68.83 \\
\hline \hline
\end{tabular}

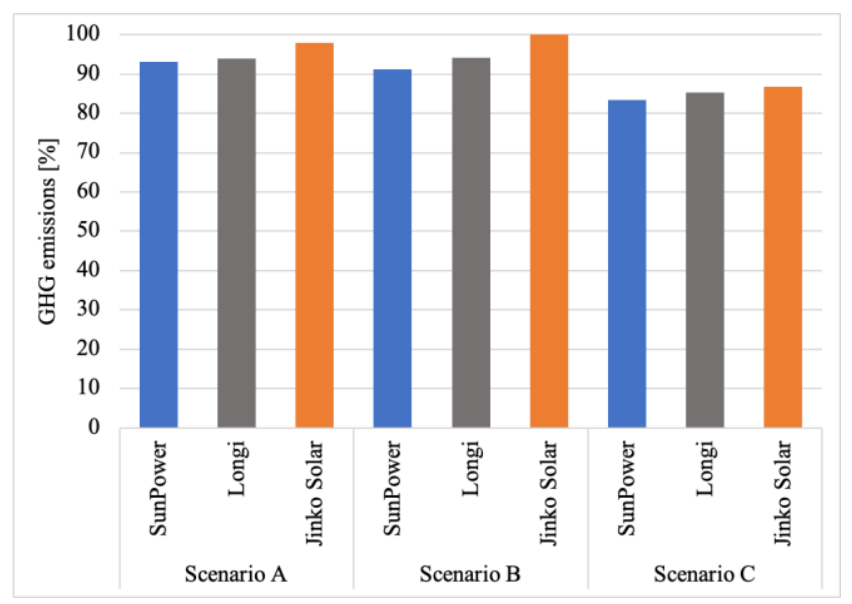

Fig. 3. Comparison of GHG emissions rates in percentage.

\section{CONCLUSION}

In this study, the effect of PV module degradation on the lifecycle GHG emissions is demonstrated. The results suggest that the PR value of 0.75 , as recommended by the IEA-PVPS, is acceptable for GHG emissions estimation of a rooftop PV system. Nevertheless, determining the PR considering the PV module's actual power temperature coefficient resulted in a more accurate result. It can also be concluded that considering the PV module degradation factor when evaluating an LCA of $\mathrm{PV}$ system is crucial. It has a significant influence on the results, as the effect of degradation will increase with longer system's operational year. The study also concludes that a lower PV module degradation rate is favorable, and research and development efforts focusing on lowering the module degradation rate in the future will indirectly benefit in mitigating the impact of global warming caused by GHG emissions.

\section{ACKNOWLEDGMENT}

This work is supported in part by the Fundamental Research Grant Scheme (FRGS), Ministry of Education (Ref: 600IRMI/FRGS 5/3 (221/2019) and Universiti Teknologi MARA (UiTM) Malaysia.

\section{REFERENCES}

[1] K. Kato, A. Murata, and K. Sakuta, "An evaluation on the life cycle of photovoltaic energy system considering production energy of offgrade silicon," Solar Energy Materials and Solar Cells, vol. 47, no. 1-4, pp. 95-100, Oct. 1997, doi: 10.1016/S0927-0248(97)00029-9.

[2] E. A. Alsema, "Energy pay-back time and $\mathrm{CO} 2$ emissions of PV systems," Progress in Photovoltaics: Research and Applications, vol. 8, no. 1 , pp. 17-25, Jan. 2000, doi: 10.1002/(SICI)1099159X(200001/02)8:1<17::AID-PIP295>3.0.CO;2-C.

[3] U. Desideri, S. Proietti, F. Zepparelli, P. Sdringola, and S. Bini, "Life Cycle Assessment of a ground-mounted $1778 \mathrm{kWp}$ photovoltaic plant and comparison with traditional energy production systems," Applied Energy, vol. 97, pp. 930-943, Sep. 2012, doi: 10.1016/j.apenergy.2012.01.055.

A. Beylot et al., "Environmental impacts of large-scale grid-connected ground-mounted PV installations," Renewable Energy, vol. 61, pp. 2-6, Jan. 2014, doi: 10.1016/j.renene.2012.04.051.

[5] A. F. Sherwani, J. A. Usmani, and Varun, "Life cycle assessment of solar PV based electricity generation systems: A review," Renewable and Sustainable Energy Reviews, vol. 14, no. 1, pp. 540-544, Jan. 2010, doi: 10.1016/j.rser.2009.08.003.

[6] J. Peng, L. Lu, and H. Yang, "Review on life cycle assessment of energy payback and greenhouse gas emission of solar photovoltaic systems," Renewable and Sustainable Energy Reviews, vol. 19, pp. 255-274, Mar. 2013, doi: 10.1016/j.rser.2012.11.035.

[7] V. Baharwani, N. Meena, A. Dubey, U. Brighu, and J. Mathur, "Life Cycle Analysis of Solar PV System: A Review," International Journal of Environmental Research and Development, vol. 4, no. 2, pp. 183-190, 2014, [Online]. Available: http://www.ripublication.com/ijerd_spl/ijerdv4n2spl_14.pdf.

[8] J. H. Wong, M. Royapoor, and C. W. Chan, "Review of life cycle analyses and embodied energy requirements of single-crystalline and multi-crystalline silicon photovoltaic systems," Renewable and Sustainable Energy Reviews, vol. 58, pp. 608-618, May 2016, doi: 10.1016/j.rser.2015.12.241.

[9] S. Gerbinet, S. Belboom, and A. Léonard, "Life Cycle Analysis (LCA) of photovoltaic panels: A review," Renewable and Sustainable Energy Reviews, vol. 38, pp. 747-753, Oct. 2014, doi: 10.1016/j.rser.2014.07.043. 
[10] N. A. Ludin et al., "Prospects of life cycle assessment of renewable energy from solar photovoltaic technologies: A review," Renewable and Sustainable Energy Reviews, vol. 96, pp. 11-28, Nov. 2018, doi: 10.1016/j.rser.2018.07.048.

[11] C. Lamnatou and D. Chemisana, "Photovoltaic-green roofs: a life cycle assessment approach with emphasis on warm months of Mediterranean climate," Journal of Cleaner Production, vol. 72, pp. 57-75, Jun. 2014, doi: 10.1016/j.jclepro.2014.03.006.

[12] M. Bravi, M. L. Parisi, E. Tiezzi, and R. Basosi, "Life cycle assessment of a micromorph photovoltaic system," Energy, vol. 36, no. 7, pp. 4297-4306, Jul. 2011, doi: 10.1016/j.energy.2011.04.012.

[13] M. J. (Mariska) de Wild-Scholten, "Energy payback time and carbon footprint of commercial photovoltaic systems," Solar Energy Materials and Solar Cells, vol. 119, pp. 296-305, Dec. 2013, doi: 10.1016/j.solmat.2013.08.037.

[14] W. Luo et al., "A comparative life-cycle assessment of photovoltaic electricity generation in Singapore by multicrystalline silicon technologies," Solar Energy Materials and Solar Cells, vol. 174, no. August 2017, pp. 157-162, Jan. 2018, doi: 10.1016/j.solmat.2017.08.040.

[15] R. Frischknecht, P. Stolz, G. Heath, M. Raugei, P. Sinha, and M. de Wild-Scholten, "Methodology Guidelines on Life Cycle Assessment of Photovoltaic Electricity, 4th edition, IEA PVPS Task 12, International Energy Agency Photovoltaic Power Systems Programme," 2020. doi: 10.13140/RG.2.2.15574.88648.

[16] A. M. Omar, S. Shaari, and S. I. Sulaiman, Grid-Connected Photovoltaic Power Systems Design. Sustainable Energy Development Authority Malaysia, 2012.

[17] A. Ndiaye, A. Charki, A. Kobi, C. M. F. Kébé, P. A. Ndiaye, and V. Sambou, "Degradations of silicon photovoltaic modules: A literature review," Solar Energy, vol. 96, pp. 140-151, Oct. 2013, doi: 10.1016/j.solener.2013.07.005.

[18] A. Phinikarides, N. Kindyni, G. Makrides, and G. E. Georghiou, "Review of photovoltaic degradation rate methodologies," Renewable and Sustainable Energy Reviews, vol. 40, pp. 143-152, Dec. 2014, doi: 10.1016/j.rser.2014.07.155.

[19] N. Jungbluth, M. Stucki, K. Flury, R. Frischknecht, and S. Buesser, "Ecoinvent 3.5 dataset documentation: electricity production, photovoltaic, $3 \mathrm{kWp}$ slanted-roof installation, single-Si, panel, mounted - MY," 2018 https://v35.ecoquery.ecoinvent.org/Details/PDF/A3571118-D1A84AFB-9830-2DF85049444C/06590A66-662A-4885-8494AD0CF410F956.

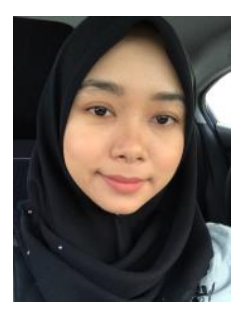

Atiqah Hamizah Mohd Nordin obtained her bachelor's degree in Electrical and Electronic Engineering from Universiti Kebangsaan Malaysia (UKM) in 2008. In 2012, she received her master's degree in Electrical Engineering (Power) from Universiti Teknologi MARA (UiTM). Currently she is pursuing her Ph.D. in Electrical Engineering (Life cycle assessment of solar photovoltaic) in UiTM. She is a senior lecturer at Department of Electrical Engineering in UiTM Johor, Pasir Gudang Campus.

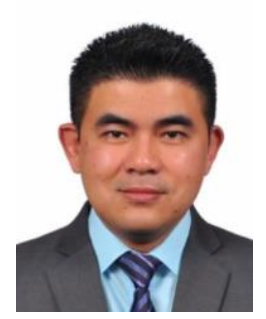

Shahril Irwan Sulaiman holds a Ph.D. in Electrical Engineering from Universiti Teknologi MARA, Malaysia. He obtained his M.EngSc in Photovoltaic Engineering from University of New South Wales, Australia, and B.Eng in Electrical \& Electronics from Universiti Tenaga Nasional, Malaysia. $\mathrm{He}$ is an associate professor in the Faculty of Electrical Engineering, Universiti
Teknologi MARA, Malaysia, and the Head of Green Energy Research Centre. Besides conducting numerous contract-based research, he has been assisting the national photovoltaic industry and the government for more than a decade. He regularly conducts competency-based training related to design, installation, testing \& commissioning, operation, and maintenance of both grid-connected photovoltaic systems and stand-alone photovoltaic systems. He is also a member of the standards working group on photovoltaic systems and has been prominently involved in preparing various policies and guidelines related to photovoltaic systems in Malaysia.

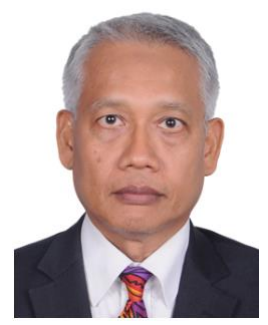

Sulaiman Shaari is a professor at the Faculty of Applied Sciences, UiTM. He received his Bachelor in Physics in 1984 from Kansas State University, USA, MSc in Physics in 1987 from University of Missouri, USA, and Ph.D. in Photovoltaic Systems from De Montfort University, UK, in 1998. He actively engaged in various activities at the international and national levels. He has represented the Government of Malaysia (GoM) at many international programs, including International Energy Agency Photovoltaic Power Systems (IEA PVPS) for Task 11 and 13. He also has been engaged in various GoM and GoMlinked agencies since the mid-1990s in providing expert services on PV systems design, training, evaluation, and involved in preparing various policies and guidelines related to photovoltaic systems in Malaysia. $\mathrm{He}$ is currently Vice President II of the Malaysian Photovoltaic Industry Association (MPIA); Secretary General of the Asian Photovoltaic Industry Association (APVIA); Master Trainer for PV Systems in Malaysia for the government and industry; and Chairman of the Working Group for PV Standards in Malaysia.

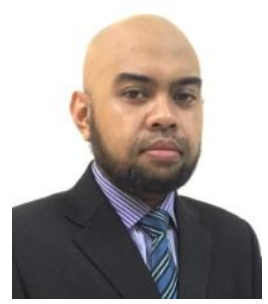

Rijalul Fahmi Mustapa obtained his diploma (2005), bachelor (2009), master (2013), and Ph.D. (2020). degrees in Electrical Engineering from UiTM. His research interest is in field of baseline energy modeling. He is a senior lecturer at Department of Electrical Engineering in UiTM Johor, Pasir Gudang Campus. 